\title{
RANCANG BANGUN SISTEM UJIAN ONLINE BERBASIS WEB DI SMK PEMBANGUNAN KABUPATEN ROKAN HILIR-RIAU
}

\author{
Volvo Sihombing ${ }^{1}$, Nimrot Siahaan ${ }^{2)}$ \\ ${ }^{1}$ Fakultas Sains dan Teknologi, Universitas Labuhanbatu \\ email: volvolumbantoruan@gmail.com \\ ${ }^{2}$ Fakultas Hukum, Universitas Labuhanbatu \\ email: Nimrotsiahaan4@gmail.com
}

\begin{abstract}
SMK Pembangunan an online examination system is analyzed which is one part of the distance education system through internet technology media. Exams conducted by most educational institutions, therefore, researchers will overcome by designing a web-based online exam system design, to facilitate the community and schools, in the world of education in this case the School is still carried out conventionally. The concept of an online exam that is not related to space and time can be a solution to the constraints that exist in conventional examination methods. This system aims to make it easier for teachers to provide exams and the process of providing effective and efficient examination scores because the assessment process is given directly when students complete the exam. The study was conducted by observing the system directly so that the results of the analysis of the system needs were obtained. As a basis and reference for making an online exam system, literature study is then made to design a system database using DFD and ERD. The implementation of this online exam system is made with facilities including admin, teacher, and students which will produce output values.
\end{abstract}

Keywords: Online Testing System, web, PHP

\section{PENDAHULUAN}

Pelaksanaan ujian membutuhkan kertas dan alat tulis, serta melakukan audit penilaian secara manual yang dilakukan oleh guru, sehingga standar pengaplikasian ujian dapat berproses lama dan memakan banyak biaya.

Oleh karena itu dirancang sebuah system ujian online berbasis web, untuk memudahkan masyarakat dan sekolah, didalam dunia pendidikan, ujian konvensional digunakan sebagai kegiatan untuk mengetahui hasil belajar siswa. Ujian konvensional menggunakan media kertas dan alat tulis sebagai penunjang kegiatan ujian.

Kecurangan dalam dunia pendidikan akan terus mengakar selama masyarakat (siswa/guru/orangtua) memiliki persepsi bahwa nilai akademis adalah tolak ukur prestasi, kebanggaan, serta satu-satunya indikator dan 'jembatan' dalam meraih jenjang karir, prospek kerja, dan kesuksesan finansial di masa mendatang [1]. Selama persepsi itu masih melekat dalam masyarakat atau para orang tua akan cenderung menuntut anak-anaknya mendapat nilai akademis yang tinggi secara konsisten. Para guru akan fokus pada prestasi, nilai dan hal-hal yang bisa menjadi simbol status sosial sekolah ketimbang berorientasi untuk bagaimana mengembangkan potensi serta pengalaman belajar siswa yang seru dan menyenangkan

Ujian online yaitu ujian berbasis web Untuk dapat memudahkan para siswa dalam melakukan ujian dan mendapatkan informasi hasil ujian yang cepat. Kesalahan dalam menginputkan nilai atau memasukkan kedalam daftar buku Nilai siswa menjadi masalah utama [2].

\section{METODE PENELITIAN}

Analisis kebutuhan dilakukan melalui metode observasi dan wawancara. Observasi dilakukan pada tanggal 9 Agustus 2019 di SMK Pembangunan, dengan mengamati proses ujian Metode Wawancara dengan tujuan untuk mencari informasi mengenai proses penyelenggaraan ujian dan spesifikasi produk yang dibutuhkan oleh pihak sekolah. Kebutuhan yang diperlukan oleh sekolah adalah sistem ujian yang efektif dan efisien. Untuk memenuhi kebutuhan tersebut, diperlukan perangkat lunak yang sesuai dengan kebutuhan di SMK Pembangunan.

Desain Software Desain perangkat lunak meliputi desain basis data, Entity Relation Diagram, dan desain interface. Proses desain 
perangkat lunak ujian online berbasis web dijelaskan pada bagian berikut ini :

a. Desain Basis Data Proses pembuatan data pada aplikasi dapat dipermudah dengan menggunakan database sebagai media penyusun data.

Operasi basis data yang dapat dilakukan adalah Update Soal user, hapus data user, membuat soal ujian online, hapus soal ujian online, menyimpan data ujian online dan hapus data ujian online. Hal yang terpenting pada proses desain basis data adalah membuat soal ujian online dan menyimpan soal ujian online.

Permasalahan yang diteliti pada penelitian kali ini merupakan proses ujian dan penyimpanan data ujian yang dibuat secara soft file pada aplikasi ujian online berbasis web.

Teknologi dan Informasi merupakan dua hal yang tidak dapat dipisahkan saat ini, hal ini terlihat dari proses untuk mendapatkan informasi yang dapat diperoleh secara cepat, tepat, dan akurat dengan didukung oleh kemajuan teknologi [3], [4].

b. Entiti Relationship Diagram Model Entity Relationship merupakan Model ini dirancang untuk menggambarkan persepsi dari pemakai dan berisi obyek-obyek dasar yang disebut entity dan hubungan antar entityentity yang disebut relationship.

Pada model entity relationship data yang ada dalam dunia nyata ditransformasikan dengan memanfaatkan perangkat konseptual menjadi sebuah diagram, yaitu diagram ER (Entity Relationship). Diagram ER (entity relationship) melengkapi penggambaran grafik dari struktur logika. Dengan kata lain, diagram entity relationship menggambarkan arti dari aspek data seperti bagaimana entity, atribut, dan relationship yang disajikan. Sebelum membuat diagram entity relationship, tentu harus memahami betul data yang diperlukan dan ruang lingkup kegunaan data.

Entitiy relationship soal ujian online berbasis web menjelaskan tentang ke-3 (tiga) pengguna diantaranya : administrator, siswa, Operator guru dihubungkan dengan simbol relasi yang menginisialkan soal ujian online berbasis web.

\section{HASIL DAN PEMBAHASAN}

Sistem yang dihasilkan terdiri dari hasil atau tampilan menu, sub menu, halaman masukan (Input sistem) dan laporan (Output sistem) [5].

\subsection{Metode Perancangan Sistem 3.2.1 Context Diagram}

Diagram konteks adalah diagram yang terdiri dari suatu proses mengambarkan ruang lingkup suatu sistem.

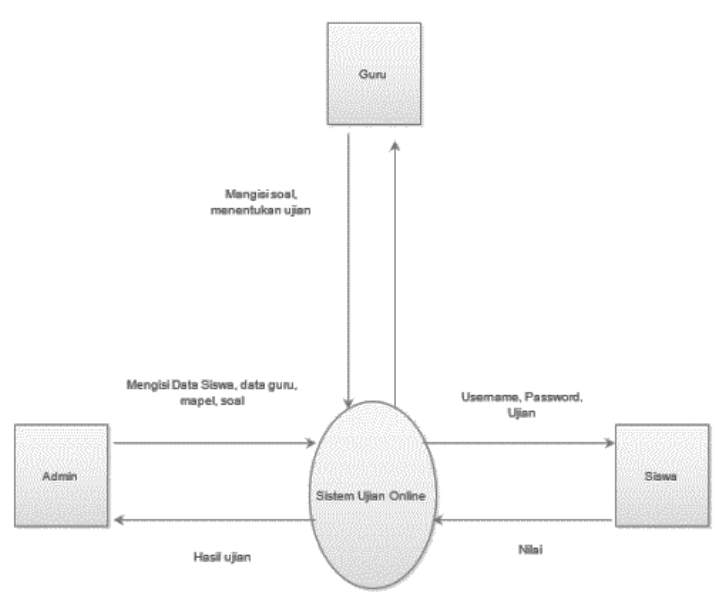

Gambar 1. Diagram konteks

\subsubsection{Rancangan Proses}

DFD ( Data Flow Diagram) diagram aliran data merupakan model dari sistem untuk menggambarkan pembagian sistem ke modul yang lebih kecil. Salah satu keuntungan menggunakan diagram aliran data adalah memudah pemakai atau user yang kurang menguasai bidang komputer untuk mengerti sistem yang akan dikerjakan [6][7].

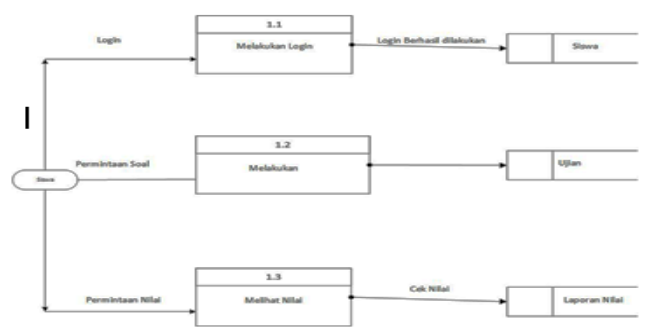

Gambar 2. DFD Level 0

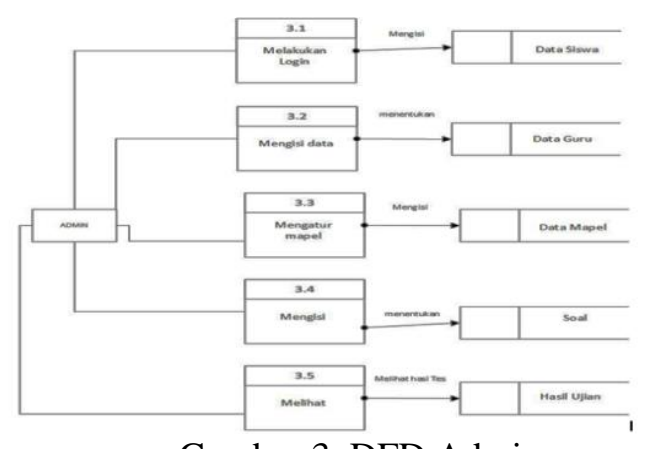

Gambar 3. DFD Admin 


\subsubsection{Rancangan Basis Data}

Relasi merupakan hubungan yang terjadi pada suatu tabel dengan tabel lainnya yang berfungsi untuk mengatur operasi suatu database. Hubungan atau relasi data biasanya ditunjukkan dengan kunci (key) dari tiap file yang ada. Data merupakan fakta atau nilai (value) yang tercatat atau merepresentasikan deskripsi dari suatu objek [8]

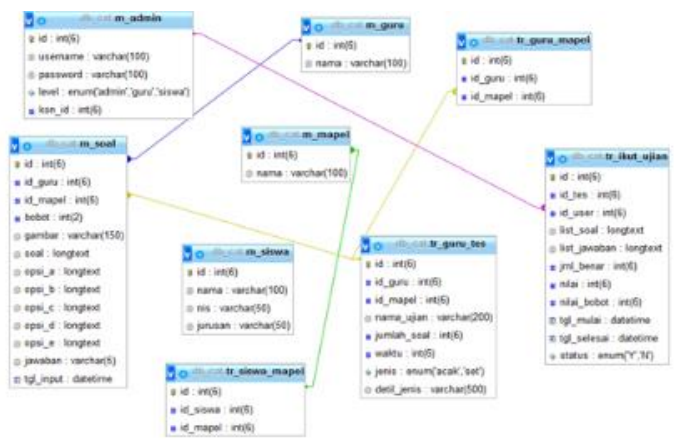

Gambar 3. Relasi antar tabel

\subsubsection{Rancangan Interface}

Tampilan desain utama dalam ujian Online di SMK Pembangunan

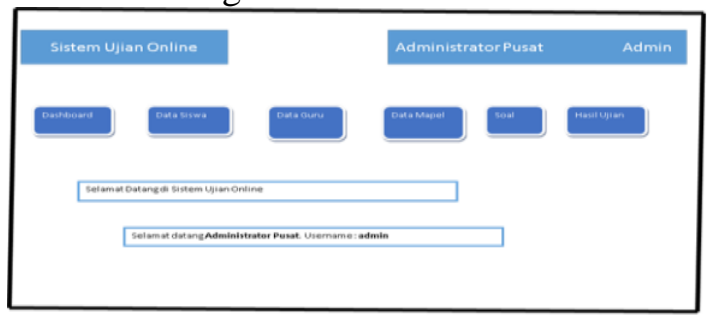

Gambar 4. Rancangan Halaman Utama

\subsubsection{Rancangan halaman Siswa}

Rancangan ini menginputkan data siswa yang akan ujian

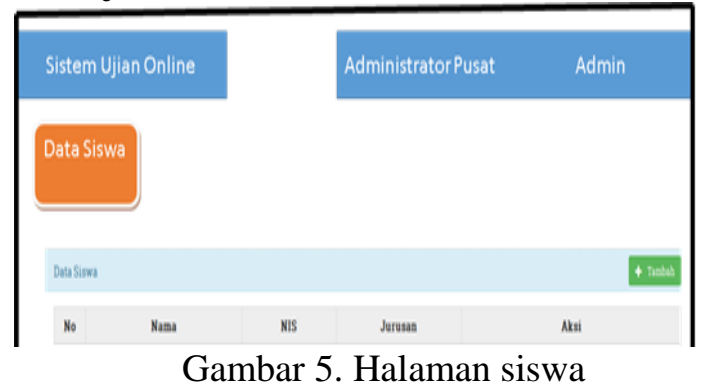

\subsubsection{Rancangan halaman Guru}

Rancangan ini guru menginputkan soal yang akan diujikan kepada siswa sesuai jadwal dan bidang studi guru.

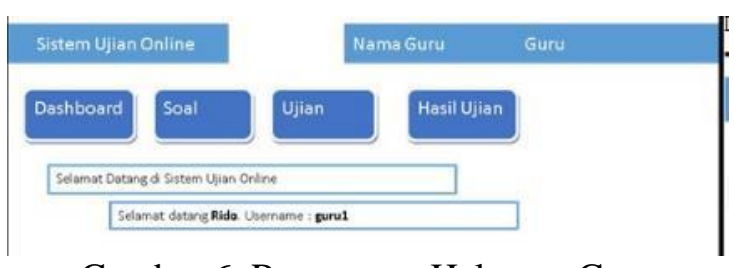

Gambar 6. Rancangan Halaman Guru

\subsubsection{Rancangan Halaman Input}

a. Login

Halaman login admin merupakan halaman yang memiliki tingkatan akun tertinggi. Seorang admin dapat mengakses semua data yang berada pada Sistem ujian online berbasis web.

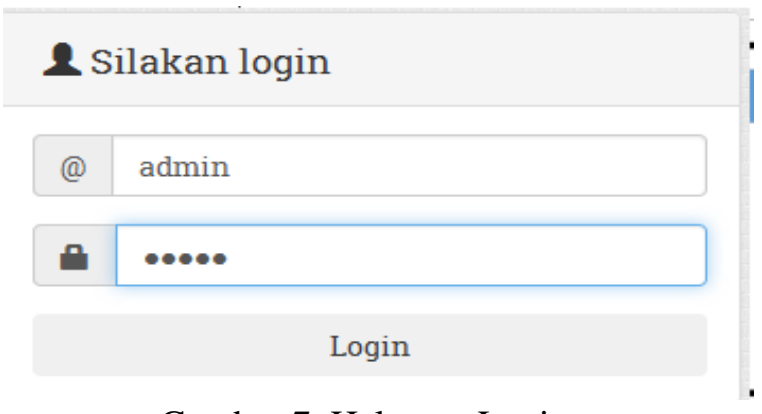

Gambar 7. Halaman Login

b. Halaman utama admin

Setelah melakukan login Sistem ujian online, admin berada pada tampilan halaman utama admin yang menampilkan data-data admin diantaranya adalah data siswa, data guru, data mapel, data, soal, hasil ujian.

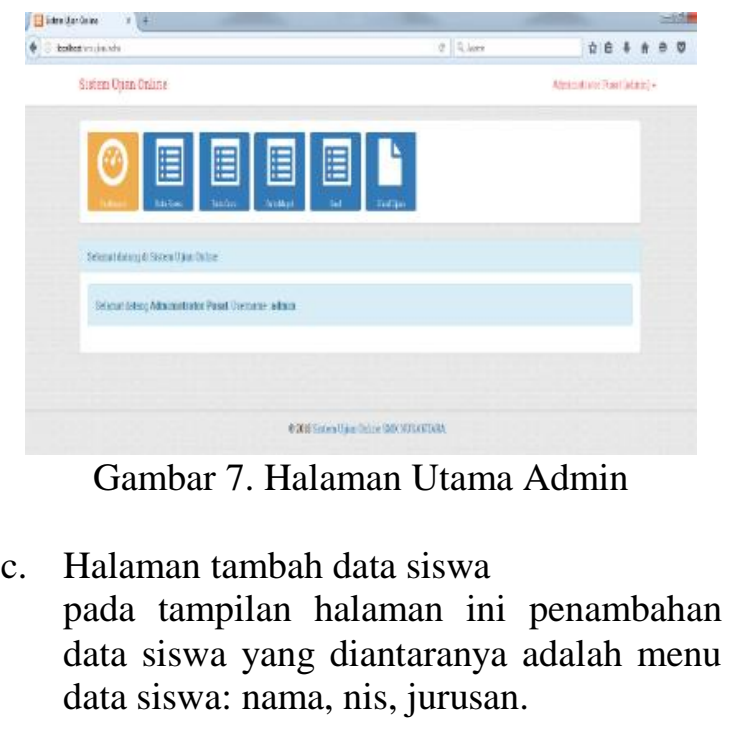




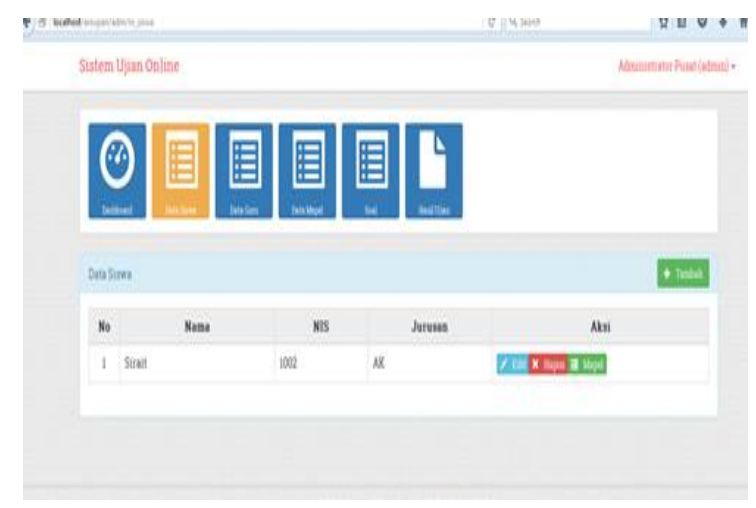

Gambar 8. Data Siswa

d. Input Soal

Halaman tambah soal ujian online merupakan halaman yang berfungsi sebagai penampil judul soal ujian, Mapel, guru, gambar soal, bobot, soal, dana A, B, C, D, dan E

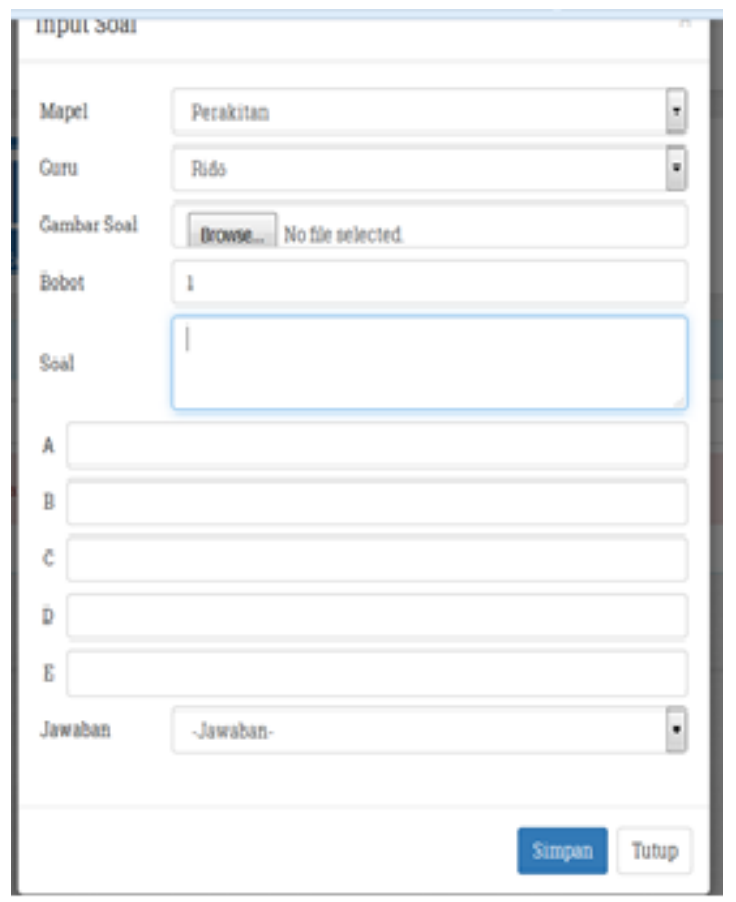

Gambar 9. Input soal

e. Hasil Ujian

Halaman Hasil Ujian berfungsi menampilkan semua nilai siswa yang telah dikerjakan oleh siswa. Pada halaman kiri bawah terdapat tombol cetak yang ingin melakukan print nilai.

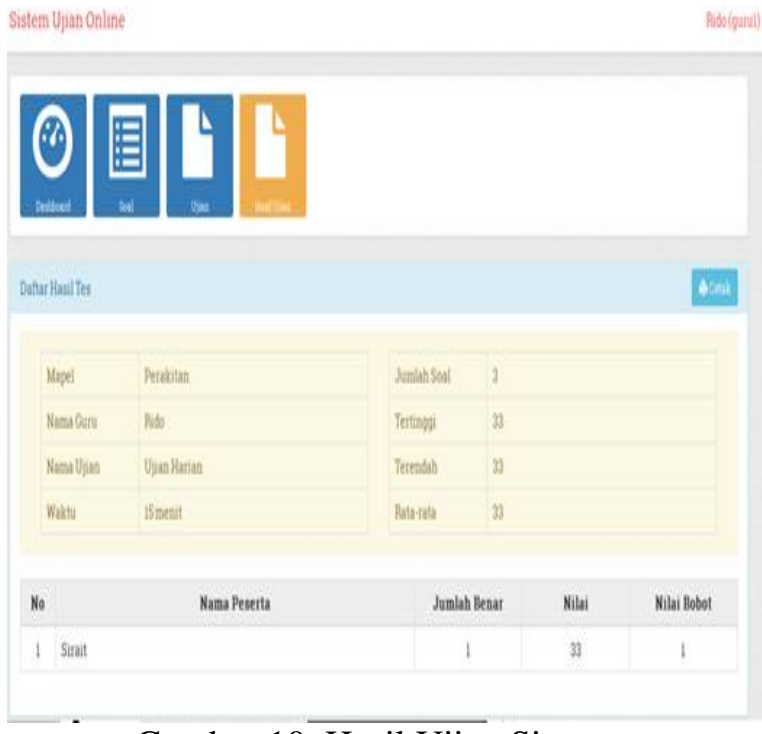

Gambar 10. Hasil Ujian Siswa

\section{KESIMPULAN}

Berdasarkan hasil penelitian yang penulis lakukan di SMK Pembangunan dapat diambil kesimpulan bahwa :

1. Soal pada ujian online ini menggunakan sistem random sehingga siswa ketika ujian tidak melakukan curang.

2. Adanya fasilitas timer otomatis sehingga apabila waktu ujian yang telah diberikan telah habis, maka sistem akan langsung logout computer otomatis mati,

\section{REFERENSI}

[1] A. Ardian, I. Purnama, and V. Sihombing, "Perancangan Aplikasi Pengolah Data Siswa Berbasis Android (Studi Kasus : Mis Nurul Huda Labuhan Batu Selatan)," Pengabdi. Masy. Ika Bina En Pabolo, vol. 1, no. 1, pp. 4053, 2019.

[2] F. Rohman, A. Bayu, H. Yanto, and N. Sutarsih, "Rancang Bangun Sistem Informasi Ujian Online Berbasis Web Menggunakan Metode Waterfall (Studi Kasus: SMK Darma Nusantara Pandeglang)," Ijns.org Indones. J. Netw. Secur., vol. 7, no. 3, pp. 22-27, 2018.

[3] V. M. M. Siregar, "Sistem Informasi Pendataan Logistik Aktiva Tetap PT. Bank Central Asia, Tbk Kantor Cabang Pematangsiantar," SISTEMASI, vol. 7, no. September, pp. 250-258, 2018.

[4] V. M. M. Siregar, H. Sugara, and I. M. Siregar, "Perancangan Sistem Informasi 
Pendataan Barang Pada PT. Serdang Hulu," J. Comput. Bisnis, vol. 12, no. 2, pp. 111-117, 2018.

[5] H. A. Simbolon and V. M. M. Siregar, "Perancangan Sistem Informasi Berbasis E-Commerce Untuk Peningkatan Penjualan Produk Jersey Olah Raga," J. Tek. Inf. dan Komput., vol. 1, no. 2, pp. 49-54, 2018.

[6] V. Sihombing, "Sistem Informasi Penjualan Mobil Suzuki Di Dealer Bagan Batu," SISTEMASI, vol. 7, no. 2, pp. 113-119, 2018.

[7] V. Sihombing, "Aplikasi Simade (Sistem Informasi Manajemen Desa) Dalam Meningkatkan Pelayanan Administrasi di Kepenghuluan Bakti Makmur Kecamatan Bagan Sinembah Kab. Rokan Hilir Riau," SISTEMASI, vol. 7, no. September, pp. 292-297, 2018.

[8] V. M. M. Siregar, H. Sugara, and G. A. Purba, "Aplikasi Pencatatan Laporan Penjualan Kita-Kita.Net Berbasis Web," TEKINKOM, vol. 2, no. 1, pp. 80-86, 2019. 